\title{
High-resolution array CGH clarifies events occurring on 8p in carcinogenesis
}

\author{
Susanna L Cooke ${ }^{1,2}$, Jessica CM Pole ${ }^{1}$, Suet-Feung Chin ${ }^{2}$, Ian O Ellis ${ }^{3}$, \\ Carlos Caldas ${ }^{2}$ and Paul AW Edwards*1
}

\begin{abstract}
Address: ${ }^{1}$ Department of Pathology and Hutchison/MRC Research Centre, University of Cambridge, Cambridge, UK, ${ }^{2}$ CRUK Cambridge Research Institute and Department of Oncology, University of Cambridge, Cambridge, UK and ${ }^{3}$ Department of Histopathology, Nottingham City Hospital NHS Trust and University of Nottingham, Nottingham, UK

Email: Susanna L Cooke - susanna.cooke@cancer.org.uk; Jessica CM Pole - jp339@mole.bio.cam.ac.uk; Suet-Feung Chin - SuetFeung.Chin@cancer.org.uk; Ian O Ellis - ian.ellis@nottingham.ac.uk; Carlos Caldas - Carlos.Caldas@cancer.org.uk;

Paul AW Edwards* - pawe1@cam.ac.uk

* Corresponding author
\end{abstract}

Published: 7 October 2008

BMC Cancer 2008, 8:288 doi:10.1 |86/|47|-2407-8-288

This article is available from: http://www.biomedcentral.com/I47I-2407/8/288

(C) 2008 Cooke et al; licensee BioMed Central Ltd.

This is an Open Access article distributed under the terms of the Creative Commons Attribution License (http://creativecommons.org/licenses/by/2.0), which permits unrestricted use, distribution, and reproduction in any medium, provided the original work is properly cited.
Received: 4 June 2008

Accepted: 7 October 2008

\begin{abstract}
Background: Rearrangement of the short arm of chromosome 8 (8p) is very common in epithelial cancers such as breast cancer. Usually there is an unbalanced translocation breakpoint in $8 \mathrm{p} / 2(29.7$ $\mathrm{Mb}-38.5 \mathrm{Mb}$ ) with loss of distal 8p, sometimes with proximal amplification of 8p II-I2. Rearrangements in $8 \mathrm{pl} \mathrm{I}-\mathrm{I} 2$ have been investigated using high-resolution array $\mathrm{CGH}$, but the first $30 \mathrm{Mb}$ of $8 \mathrm{p}$ are less well characterised, although this region contains several proposed tumour suppressor genes.
\end{abstract}

Methods: We analysed the whole of $8 \mathrm{p}$ by array $\mathrm{CGH}$ at tiling-path BAC resolution in 32 breast and six pancreatic cancer cell lines. Regions of recurrent rearrangement distal to $8 \mathrm{p} / 2$ were further characterised, using regional fosmid arrays. FISH, and quantitative RT-PCR on over 60 breast tumours validated the existence of similar events in primary material.

Results: We confirmed that $8 p$ is usually lost up to at least $30 \mathrm{Mb}$, but a few lines showed focal loss or copy number steps within this region. Three regions showed rearrangements common to at least two cases: two regions of recurrent loss and one region of amplification. Loss within 8p23.3 $(0 \mathrm{Mb}-2.2 \mathrm{Mb})$ was found in six cell lines. Of the genes always affected, ARHGEFI 0 showed a point mutation of the remaining normal copies in the DU4475 cell line. Deletions within $12.7 \mathrm{Mb}-19.1$ $\mathrm{Mb}$ in 8p22, in two cases, affected TUSC3. A novel amplicon was found within 8p21.3 (19.1 Mb $23.4 \mathrm{Mb}$ ) in two lines and one of 98 tumours.

Conclusion: The pattern of rearrangements seen on 8p may be a consequence of the high density of potential targets on this chromosome arm, and ARHGEFIO may be a new candidate tumour suppressor gene.

\section{Background}

Rearrangements of the short arm of chromosome 8 (8p) are one of the most common genetic events in breast [1-
3], pancreatic [4] and many other epithelial carcinomas [5]. Although these rearrangements have been studied using a variety of techniques, including cytogenetics, CGH 
(comparative genomic hybridisation), array CGH and LOH (loss of heterozygosity) analysis [1-4], their resolution, with the exception of studies on 8 p12 which are discussed below, has been insufficient to provide a feasibly small number of candidate genes for further analysis.

Loss of heterozygosity ( $\mathrm{LOH}$ ) studies suggest that there are at least three tumour suppressor genes on $8 \mathrm{p}$, in bands 8p23, 8p22, and 8p21, lost in several epithelial tumour types [6-8]. The highest resolution of these studies is just over $1 \mathrm{Mb}$, showing that bladder tumours have a common region of $\mathrm{LOH}$ between microsatellite markers D8S504 (1.0 Mb) and D8S264 (2.1 Mb) in 8p23.3 [8]. In support of this a lower resolution LOH study of ovarian adenocarcinomas identifies D8S264 (2.1 Mb) as showing the second highest rate of $\mathrm{LOH}$ on $8 \mathrm{p}$, with the highest rate at D8S1827 (14.9 Mb) in 8p22 [7].

Cytogenetic and array CGH studies suggest that distal 8p is frequently lost through an unbalanced translocation that breaks in 8p11-12 [3,9]. The 8.8 Mb between $29.7 \mathrm{Mb}$ and $38.5 \mathrm{Mb}$, encompassing $8 \mathrm{p} 12$, is the only region of $8 \mathrm{p}$ that has been extensively studied at high resolution, using tiling-path BAC array CGH $[10,11]$. The translocation breakpoints are usually within, or proximal to, the chromosome band 8p12 and several of them are within the NRG1 (neuregulin 1) gene (32.2 Mb; midpoint on NCBI Build 36) $[12,13]$. Most recent research has focussed on this breakpoint region and more proximal changes and array CGH has not been applied to the distal candidate regions identified by the earlier LOH studies.

The other known recurrent feature of $8 p$ rearrangements, at least in breast cancer, is amplification of 8p11-12 in $10-25 \%$ of cases, correlating with poor prognosis $[11,13-$ $15]$. This amplicon was originally suggested to target the FGFR1 (Fibroblast Growth Factor Receptor 1) gene [16], a member of the same family as FGFR2 (Fibroblast Growth Factor Receptor 2), a known oncogene and driver of amplification. However, it has subsequently been shown that FGFR1 is not always included in the minimal region of amplification and other candidate oncogenes have been suggested [11,13-15,17,18]. Detailed analysis of 8p11-12 amplification shows that there may be as many as four sub-regions of amplification [11,17], raising the possibility that there are multiple cancer-relevant genes in 8p1112.

Array CGH studies at around $1 \mathrm{Mb}$ resolution of breast [19] and pancreatic cancer [20] confirm the general pattern of loss of $8 \mathrm{p}$ but are of insufficient resolution to study individual changes and identify candidate target genes. Two tiling-path array CGH studies have been carried out on seven [21] and ten [22] breast cancer cell lines. The first mentions two changes on $8 \mathrm{p}$ [21]. MCF-7 has lost the whole of $8 \mathrm{p}$ and T47D has two small deletions in 8p23.1, although we now suggest that this is due to normal copy number variation (see results). At least two further changes - breaks at 8p12 with distal loss - are visible on the ZR-75-30 and T47D karyograms included in the supplementary data, but the raw data is not available for further analysis. The second study identifies amplification of 8p11-12 in JIMT-1 [22].

Overall the picture of events occurring on $8 \mathrm{p}$, and especially distal $8 \mathrm{p}$, is rather confused, due at least in part to the lack of high-resolution data on $8 \mathrm{p}$ rearrangements and the lack of array CGH data for the regions highlighted by $\mathrm{LOH}$ as likely to contain tumour suppressor genes. Array CGH suggests that a tumour suppressor gene is located at, or just distal to, the 8p12 breakpoint cluster [10], while $\mathrm{LOH}$ analysis suggests the existence of several more distal tumour suppressor genes [6-8]. In spite of recent analyses that might suggest a relatively small overlap in alterations across different tumour types [23], the general pattern of changes on $8 \mathrm{p}$ is similar across several tumour types and is therefore potentially driven by the same selective pressures.

Our objectives were to investigate whether there were recurrent events on $8 \mathrm{p}$ outside the well-studied 8p11-12 region; in particular to look for deletions in distal regions, previously suggested by $\mathrm{LOH}$ to harbour a tumour suppressor gene; and to try and make sense of the overall pattern of changes seen on $8 \mathrm{p}$. We set out to analyse the whole of $8 \mathrm{p}$ by tiling-path-resolution array CGH in a panel of breast cancer cell lines, and to investigate further regions of recurrent rearrangement. We had previously obtained SKY karyotypes for 27 of the 32 breast cancer cell lines used in this study. Additionally we included six pancreatic cancer cell lines that show rearrangements of $8 p$ at cytogenetic resolution http://www.path.cam.ac.uk/ $\simeq$ pawefish/index.html.

\section{Methods}

\section{Cell lines and primary tumours}

Details of cancer cell lines can be found in Additional file 1. Immortalised human breast luminal epithelial line HB4a [24] was obtained from Professor Mike O'Hare (LICR/UCL Breast Cancer Laboratory, University College, London, UK) and normal male lymphoblastoid line m62 obtained from Dr Chris Tyler-Smith (Wellcome Trust Sanger Institute, Hinxton, UK). Both were cultured in DMEM:F12 (Invitrogen, Paisley, UK).

All tumours were invasive breast carcinomas of small size $(91 \%<3 \mathrm{~cm})$ and low Nottingham Prognostic Index, collected between 1990 and 1996 as part of the Nottingham/ Tenovus series [25-29]. 65\% were ER positive. The tissue microarray consisted of over 100 breast tumours. Match- 
ing RNA, TRIzol ${ }^{\oplus}$-extracted from fresh-frozen tissue, was available for 61 of these tumours.

\section{Array construction}

For the $8 \mathrm{p}$ tiling path array, 328 overlapping BAC clones for the length of $8 p$ were selected from the $32 \mathrm{k}$ clone set available from the BACPAC Resource Centre (CHORI, CA, USA) [30]. Additional clones to close gaps were obtained from Invitrogen and the Wellcome Trust Sanger Institute. A subset of $6 \%$ of these BACs was sequenced to confirm their identity. All except one matched their expected position on the human genome. The remaining clone showed evidence of containing more than one sequence and was substituted on the final array. The selected overlapping $\mathrm{BAC}$ clones for $8 \mathrm{p}$ provided an average clone spacing of $138 \mathrm{~kb}$. A spot failure rate of around $10 \%$ resulted in an actual resolution averaging $155 \mathrm{~kb}$. For the fosmid array, 123 fosmids were obtained from the Sanger Institute, mainly covering the regions of $8 \mathrm{p} 21.3$ (27 clones between $21.59 \mathrm{Mb}$ and $22.25 \mathrm{Mb}$ ) and 8p22 (43 clones between $12.97 \mathrm{Mb}$ and $15.68 \mathrm{Mb}$ tiling three genes but not intergenic regions), identified by BAC array CGH as containing multiple rearrangements, to a resolution of $0.04 \mathrm{Mb}$. BACs were amplified by the method of Fiegler et al. [31] and printed with the custom genomic $8 \mathrm{p} 12$ array first described in Huang et al. [32] on CodeLink slides (Amersham Biosciences, Amersham, UK). Fosmids were prepared by the same method and printed as a separate array.

\section{Array hybridisation}

Array hybridisations were carried out essentially as described in Garcia et al. [14] and Pole et al. [10]. Tumour genomic DNA was labelled with Cy3-dCTP and a pool of normal female genomic DNA with Cy5-dCTP (Amersham Biosciences) using Bioprime labelling kits (Invitrogen). Samples were hybridized to arrays overnight in the presence of Cot1 DNA (Invitrogen), and washed in PBS/ $0.05 \%$ Tween-20 at room temperature, $50 \%$ formamide/ SSC at $42{ }^{\circ} \mathrm{C}$ and then again in PBS $/ 0.05 \%$ Tween- 20 . Arrays were scanned on an Axon 4100A scanner with data collected using GenePix Pro 4.1 software (Axon Instruments, CA, USA) and analyzed in Excel. For array painting, chromosomes (provided by Dr Karen Howarth, University of Cambridge, UK) were sorted by flow-cytometry and amplified by GenomiPhi (GE Healthcare, Buckinghamshire, UK) according to the method of Howarth et al. [33]. They were hybridised against GenomiPhi-amplified normal female genomic DNA.

The array performance was tested by self-self and malefemale hybridisations and using known 8p rearrangements in T47D (Additional file 2). Self-self hybridisation gave a standard deviation (SD) of \pm 0.08 and male-female hybridisation $\pm 0.04 \mathrm{SD}$. $\log _{2}$ ratio shifts in response to copy number changes were tested by hybridisation of
T47D against normal female gDNA. Copy number changes were estimated by inspection, taking into account both the shift in $\log _{2}$ ratio and the level of noise for each sample. In general a change in $\log _{2}$ ratio of 0.5 or more was scored as a change in copy number and a gain in $\log _{2}$ ratio of 2 or more was scored as amplification.

\section{Chi-squared test}

The probability of the observed distribution of rearrangements on $8 p$ occurring in the absence of any selection or pre-disposition to breakage at certain sites was calculated by chi-squared test. Chromosome 8 was divided into the major bands $(8 p 11,12,21,22,23)$ and the observed number of rearrangements in each band tested against the number expected at random according to the size of each band.

\section{Fluorescence in situ hybridization (FISH)}

Metaphase preparation and FISH was carried out as described previously $[10,34]$. Chromosome 8 paint was made using flow sorted chromosomes kindly provided by Patricia O'Brien and Professor Ferguson-Smith (University of Cambridge, UK). All BACs used for FISH were tested individually on normal (m62) metaphases for hybridisation to the correct region of chromosome 8 .

\section{FISH on paraffin embedded tumours}

Tissue microarray slides were prepared from formalinfixed paraffin embedded tissue and analysed according to the method of Chin et al. [35]. Probes for FISH on paraffin embedded tumours were prepared in the same way as for conventional FISH. A pool of three BACs, RP11-529P14 (21.8 Mb; positions are given as BAC midpoints according to NCBI Build 36), RP11-67H12 (21.9 Mb) and RP11$70 \mathrm{D} 12(22.0 \mathrm{Mb})$, was used for the test region and a pool of two BACs, RP11-381G11 (19.4 Mb) and RP11-222M11 (19.5 Mb), was used as a reference.

\section{RT-PCR}

RNA was reverse transcribed using SuperScript III Reverse Transcriptase (Invitrogen) and oligo dT primer. Quantitative real-time PCR was carried out, in triplicate, in $10 \mu \mathrm{l}$ reactions containing $1 \times$ SYBR Green PCR Master Mix (Applied Biosystems, CA, USA), 2.5 pmol both forward and reverse gene specific primer and $1 \mu \mathrm{l}$ of 10 -fold diluted cDNA. Cycling conditions were $50^{\circ} \mathrm{C}$ for $2 \mathrm{~min}$, $95^{\circ} \mathrm{C}$ for 10 min then 40 cycles of $95^{\circ} \mathrm{C}$ for $15 \mathrm{~s}, 60^{\circ} \mathrm{C}$ for $1 \mathrm{~min}$ and a final dissociation step of $95^{\circ} \mathrm{C}$ for $15 \mathrm{~s}, 60^{\circ} \mathrm{C}$ for $15 \mathrm{~s}$ and $95^{\circ} \mathrm{C}$ for $15 \mathrm{~s}$ in an ABI PRISM $7900 \mathrm{HT}$ Sequence Detection System (Applied Biosystems).

Primer sequences are given in Additional file 3. Standard curves for each primer pair were used to calculate amplification efficiency coefficients and melting curve analysis following QPCR confirmed that each primer amplified a 
single product. Relative expression levels were calculated as:

$\frac{(\text { Average Sample Ct for gene - Average reference Ct for gene })^{\text {Amplification Coefficient for gene }}}{(\text { Average Sample Ct for GAPDH - Average reference Ct for GAPDH })^{\text {Amplification Coefficient for GAPDH }}}$

For primary samples expression levels were compared to the median-expressing tumour. Purified luminal cells, purified basal cells [36] (both kindly provided by Professor Mike O'Hare, UCL, London), a range of commercial normal RNAs (Stratagene (Cambridge, UK), USBiological (Europa Bioproducts Ltd, Wicken, UK), Ambion (Huntingdon, UK), BioChain (AMS Biotechnology, Abingdon, UK), Clontech (Basingstoke, UK)), and normal breast line HB4a were used as normal controls.

\section{Results}

Array CGH results were obtained for a set of 32 breast and six pancreatic cancer cell lines (Figure 1, Additional files $4)$. Five cell lines had lost the whole of $8 p$ with respect to $8 \mathrm{q}$, five had no copy number change on $8 \mathrm{p}$, and the remaining 28 had at least one unbalanced rearrangement (Additional file 5). By chi-squared analysis the distribution of breakpoints across the different chromosome bands was non-random ( $\mathrm{p}=0.0001)$, suggesting that rearrangements of $8 \mathrm{p}$ are under selective pressure or that breaks occur non-randomly due to breakage-prone regions. We identified, in addition to the expected translocation breakpoints and amplicon in 8p11-12 (29.7 Mb - centromere), three further regions of recurrent rearrangement (Figure 1). These are located more distally on 8p: two overlapping amplicons, which defined a possible novel region of amplification in 8p21.3 (19.1 Mb - 23.4 $\mathrm{Mb})$, a region of recurrent rearrangement in 8p22 (12.7 $\mathrm{Mb}-19.1 \mathrm{Mb})$ and a region of focal recurrent loss in 8p23.3 (0 Mb - 2.2 Mb). They identify a limited number of candidate genes in these regions for further study.

Normal copy number polymorphisms were observed at around $7 \mathrm{Mb}$ in 8p23.1, where there is a high level of segmental duplication and a family of homologous and highly polymorphic genes, the defensins [37,38]. FISH with BACs RP11-185K20 (7.80 Mb; positions are given as BAC midpoints according to NCBI Build 36) and RP11$43 \mathrm{~B} 8(7.76 \mathrm{Mb})$ from this region on normal lymphoblastoid interphase nuclei confirmed copy number differences were present between the homologous chromosomes (Additional file 2).

\section{8p I I-I 2 amplicon}

As we described previously, most of the cell lines (25/28) with rearrangements of $8 \mathrm{p}$ had at least one copy number step in 8p11-12, with loss of most or all of $8 \mathrm{p}$ distal to this region. Similarly, six out of the eight amplicons found were in the known region of amplification in 8p11-12. A full analysis of these events is given in Pole et al. [10].

\section{A novel amplicon in $8 p 21.3$}

Two cell lines, MDA-MB-134 and BT-20, showed amplification in an overlapping region of 8 p21.3. This was confirmed and the amplicon further mapped by fosmid array CGH (Figures 2a and 2b, Additional file 6). Both amplicons contained the genes GFRA2 (GDNF Family Receptor Alpha-2) (21.6 Mb), DOK2 (Docking protein 2) (21.8 Mb), XPO7 (exportin 7) (21.9 Mb), NPM2 (nucleophosmin/nucleoplasmin family member 2) (21.9 Mb) and FGF17 (Fibroblast Growth Factor 17) (22.0 Mb). The centromeric edge of the amplicon in MDA-MB-134 fell within gene EPB49 (Erythrocyte membrane Protein Band 49) (22.0 Mb), whereas the amplicon in BT-20 extended proximally to encompass up to a further eighteen genes and one micro RNA. By both fosmid and BAC array CGH, the amplicon in BT-20 consisted of two levels of amplification with a step up at 22.02 Mb (Figure 2a), placing the highest level of BT-20 amplification outside the MDA-MB-134 amplicon.

FISH was used to confirm these amplifications and to investigate their structure. FISH on BT-20 with BAC RP11235B11 (23.0 Mb), from the region of highest amplification, and BAC RP11-459H21 (21.2 Mb), from the adjacent region of gain, suggested that these two regions of copy number increase were not co-localised (Figure 2c). There was one apparently normal chromosome 8 with signals from both BACs. All extra copies of the region of highest amplification were found on a single small derivative chromosome. One copy of the region of lower amplification was seen on this derivative and one extra copy was present on a separate derivative chromosome 8 .

MDA-MB-134 is known to have an 8p12 amplicon that is part of a marker chromosome containing co-amplified 8 and 11 sequences [17]. FISH on MDA-MB-134 was carried out with BAC RP11-135I5 (21.5 Mb), from the 8p21.3 amplicon, and BAC RP11-104D16 (40.2 Mb) from the 8p12 amplicon. This showed that the 8p21.3 amplicon was intermingled with the 8p12 and 11q13 amplicons on the der(?)t $(8 ; 11)$ ins $(8 ; 11)$ (Figure 2d). Incidentally, FISH also showed that the two copies of this marker chromosome are not identical but have undergone further evolution since endoreduplicating. In addition there was one apparently normal copy of chromosome 8.

Dramatic amplification of the region that was both gained in BT-20 and amplified in MDA-MB-134 was found in a single primary breast tumour, out of 98 useable tumour cores, by FISH on a primary breast tumour tissue microarray, with a pool of BACs positioned within the amplicon 


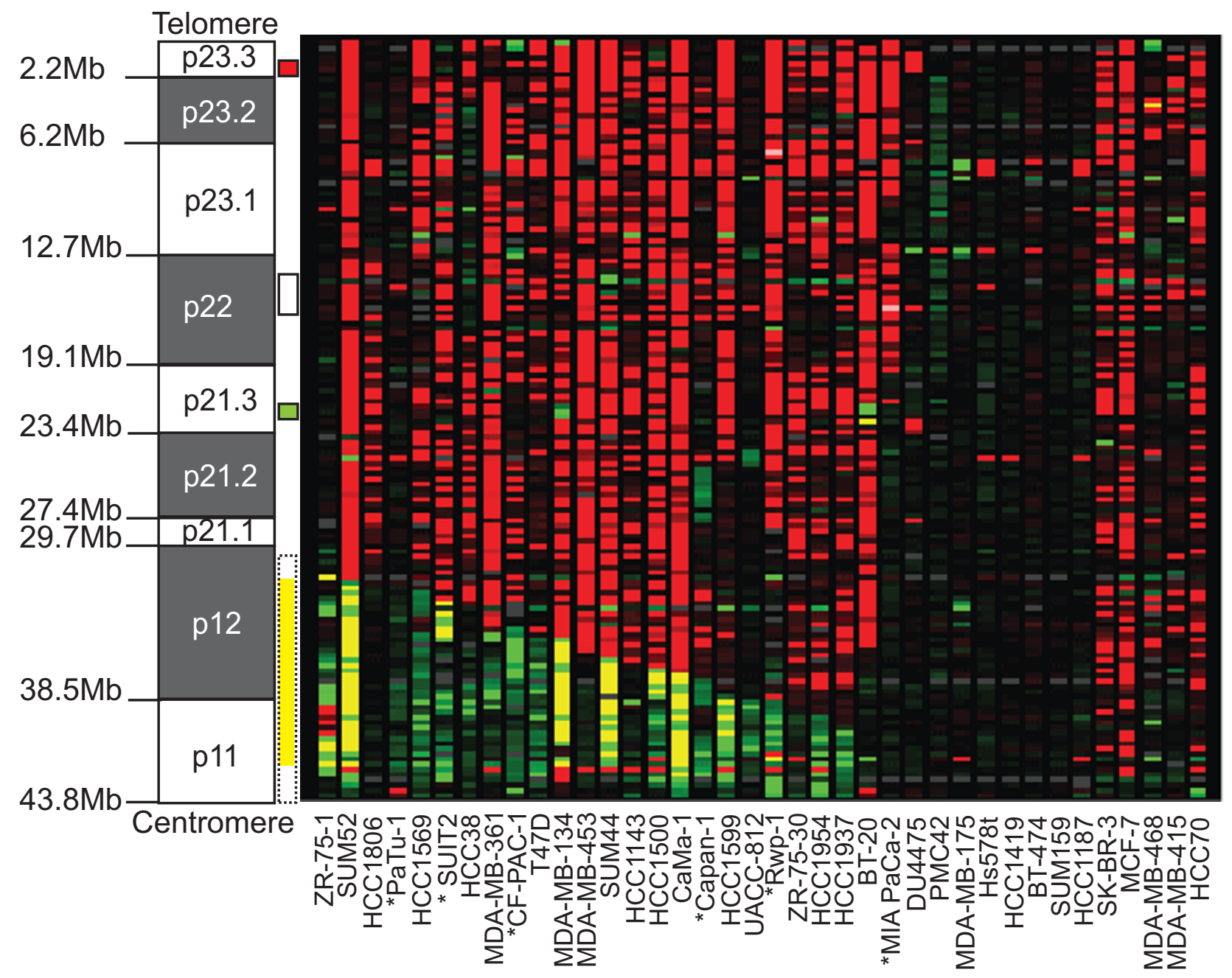

Figure I

Array CGH of 8p in 38 cancer cell lines. The ideogram shows the short arm of chromosome 8 with the position of the chromosome bands indicated on the left and regions of recurrent change represented by coloured boxes on the right of the ideogram. Previously identified positions of recurrent rearrangement $(8 \mathrm{pl} / \mathrm{I}-12)$ are indicated by a dashed outline. The novel regions identified by this study are indicated by a solid outline. For these summary boxes red indicates a common region of loss in 8p23.3, green a common region of gain/amplification in 8p21.3 and white indicates a region with various rearrangements including gain, loss and breakpoints in 8p22. Array CGH results are displayed as a heat map using CGHAnalyzer (http:// acgh.afcri.upenn.edu, [64]). The first twenty-four lines show a typical pattern of $8 p / 2$ rearrangement with breakpoints, distal loss and occasionally proximal amplification. The next four lines have atypical patterns of $8 p$ rearrangement. The final ten lines show no copy number changes within $8 p$ but the last five have lost the whole of $8 p$ with respect to $8 q$. Red, loss relative to the ploidy of the cell line; Black, no change; Green, gain; Yellow, high level amplification; Grey, no copy number data; * indicates a pancreatic line.

(21.8 Mb-22.1 Mb) and a pool positioned 2.5 Mb distal to the amplicon (19.3 Mb-19.6 Mb) (Figure 2e).

Expression of the genes within the amplicon, GFRA2, XPO7, NPM2, FGF17 and EPB49, was analysed to see if amplification had an effect on expression levels. Quantitative RT-PCR was performed on CDNA from the two cell lines that had amplification, and a further four cell lines without amplification in this region (Figure $2 \mathrm{f}$ ). DOK2 was excluded from quantitative expression studies as expression was not detectable by conventional PCR in normal breast line HB4a, BT-20 or MDA-MB-134 (results not shown). MDA-MB-134 showed over-expression of GFRA2, XPO7, NPM2 and FGF17 compared to HB4a but 


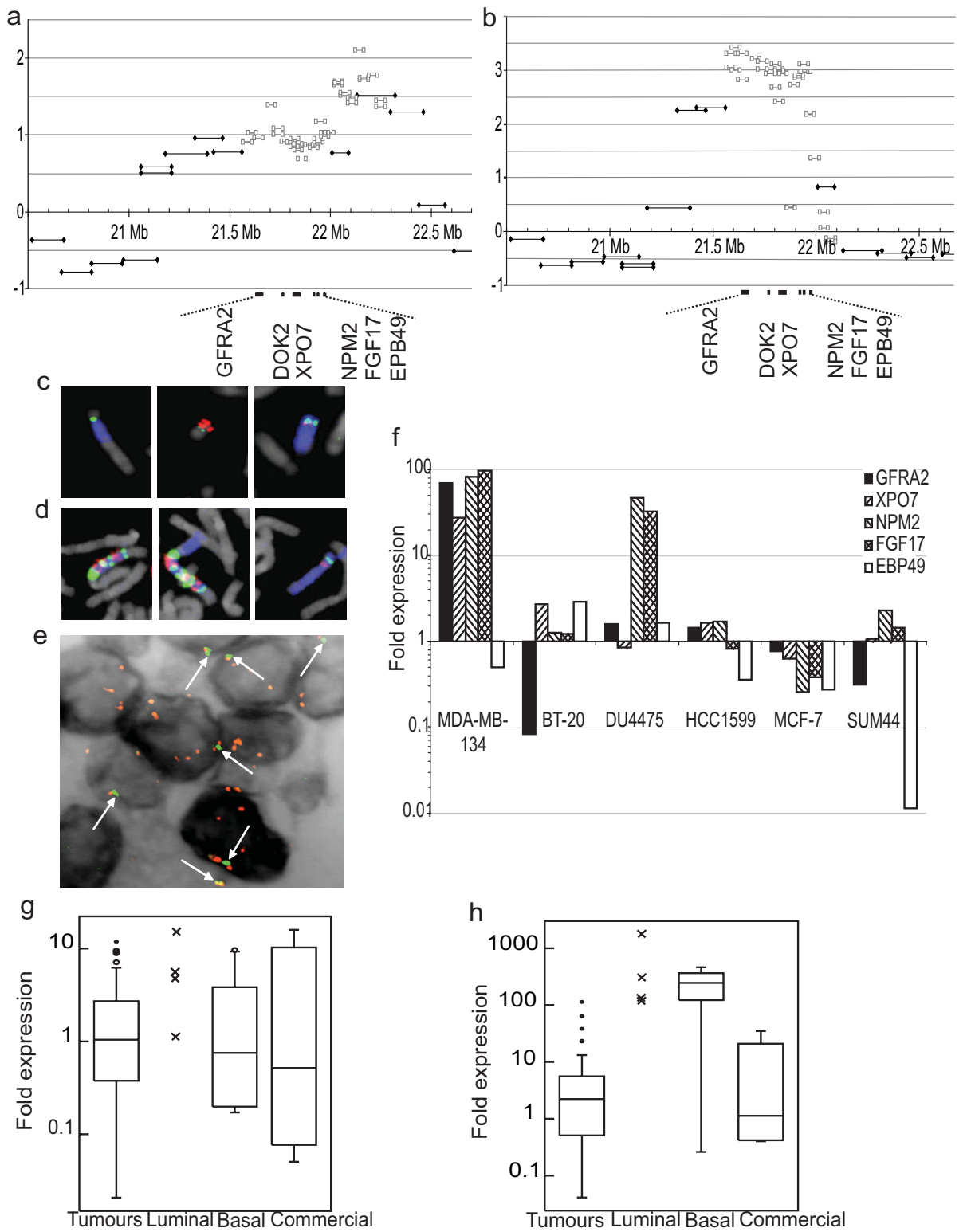

Figure 2

Analysis of the 8p2I.3 amplicon. (a) and (b) BAC and fosmid array CGH of the 8p21.3 amplicons in BT-20 and MDA-MBI 34 respectively. (a) BT-20 showed amplification between BAC clones RPI I-4 I 9 L22 (2 I. I 3 Mb; positions are given as midpoints on NCBI Build 36) and RPI I-582 J 6 (22.50 Mb). (b) MDA-MB-I 34 showed amplification between BAC clones RPI I$458 \mathrm{H} 2 \mathrm{I}(2 \mathrm{I} .28 \mathrm{Mb})$ and RPI3-600L4 (22.04 Mb). The distal edges of both amplicons fell in a region containing no known genes but extended proximally into a gene-dense region. Genes within the overlap are marked. Log $_{2}$ ratio of the fluorescence intensity is plotted against position on 8p. Grey squares, fosmids; Black diamonds, BACs. (c) FISH of the three chromosomes containing material from the 8p2I.3 amplicon in BT-20. Blue, chromosome 8 paint; Green, RPI I-459H2I (2I.29 Mb); Red, RPII235B I I (22.38 Mb). (d) FISH of the three chromosomes containing material from the 8p2I.3 and 8p I 2 amplicons in MDA-MBI34. Blue, chromosome 8 paint; Green, BAC RPI I-I35I5 (2I.49 Mb); Red, RPI I-I04DI6 (40.25 Mb). (e) FISH of the 8p2I.3 amplicon on a primary breast tumour paraffin section. Red, BAC pool positioned in the amplicon (centred at $21.9 \mathrm{Mb}$ ); Green (also indicated by arrows), BAC pool distal to the amplicon (centred at $19.5 \mathrm{Mb}$ ); Grey, inverted DAPI. (f) Expression levels of the five genes included in both the BT-20 and MDA-MB-I 34 amplicons, shown on the $y$-axis as a log 10 scale of -fold expression compared to normal breast cell line HB4a and normalised to GAPDH as an internal control. Expression levels of (g) FGFI 7 and (h) NPM2 in primary tumours and normal controls. Crosses, purified luminal samples; Open circles, possible outliers (value more than I.5X inter-quartile range above the third quartile); Filled circles, outliers (value more than $3 \times$ inter-quartile range above the third quartile). 
0.5-fold expression of EPB49, consistent with the edge of the amplicon falling within this gene (Figure 2f). BT-20 showed marginal, up to 3-fold, over-expression of XPO7 and EPB49. Interestingly, one cell line, DU4475, showed huge over-expression of NPM2 and FGF17 in the absence of amplification (Figure 2f).

Since NPM2 and FGF17 were over-expressed in two cancer cell lines, expression levels were analysed in 61 primary tumours, from the primary breast tumour series analysed by FISH, for which cDNA was available (Figures $2 \mathrm{~g}$ and $2 \mathrm{~h})$. However, cDNA was unavailable for the tumour that showed 8p21.3 amplification by FISH. For both genes, cDNA made from five commercial normal breast RNAs showed extreme variation - over 100-fold difference - in expression across the samples, highlighting the problem of identifying suitable normal controls for primary tumour samples. The variation between commercial normal samples may reflect differences in how they are obtained, for example if RNA is extracted from tissue obtained after reduction mammoplasty it may be more representative of adipocytes than breast epithelium. These technical concerns may limit the utility of commercially available normal RNA as a reference. Purified breast luminal and basal cells [36] were included as further controls and tended to be more consistent in their expression levels.

None of the tumours expressed FGF17 above the range of the control groups (Figure $2 \mathrm{~g}$ ). Three tumours expressed NPM2 at a higher level than any of the commercial controls, although at a lower level than the normal luminal and basal cells (Figure 2h). Although tumours do not express either gene outside the range of normal controls, there are four outliers/probable outliers for each gene, which have expression at significantly higher levels than the rest of the tumours (Figures $2 \mathrm{~g}$ and $2 \mathrm{~h}$ ). Due to the variability of the normal controls the most significant observation may be that there were outliers over-expressing both genes within the tumour group.

\section{8p22 rearrangements}

A cluster of copy number steps that might affect a common target gene were found between 12.9 Mb and 15.6 $\mathrm{Mb}$ in 8p22 (Figure 3a, Additional file 5). Unbalanced changes in this region were seen in four cell lines: HCC1806, SUM44, DU4475, and pancreatic line MIA PaCa-2, which has a homozygous deletion previously reported by Bashyam et al. ([4]. In addition, we recently found a reciprocal translocation breakpoint at $14.7 \mathrm{Mb}$ in HCC1187 by array painting, i.e. hybridisation of individual chromosomes to arrays [33] (Figure 3a). These rearrangements were fine-mapped to a resolution of $0.04 \mathrm{Mb}$, by array CGH on a fosmid array covering the three genes in this region, 13.0 Mb-13.4 Mb (DLC1), 14.0 Mb-14.5
Mb (SGCZ - sarcoglycan zeta) and 15.4 Mb-15.7 Mb (TUSC3) (Figure 3a, Additional file 6).

In SUM44 there were two copy number steps resulting in an extra copy of a retained fragment of the region between 13.6 Mb, within the second intron of DLC1 by fosmid array CGH, and 14.6 Mb, within SGCZ. DU4475 had a deletion between $15.4 \mathrm{Mb}$ and $15.6 \mathrm{Mb}$, virtually the same region as the homozygous deletion in MIA PaCa-2. The copy number shift observed in DU4475 was relatively small and FISH, with BAC RP11-314P10 (15.6 Mb) within the deletion and BAC RP11-480M18 (15.0 Mb) just outside it, showed that the deletion was only present on one out of the four copies of chromosome 8 present in DU4475 cells (Figure 3b).

In HCC1806 two copy number steps fell in this region (Figure 3a). Comparison of array painting results [33] and BAC array CGH allowed us to assign these to two separate copies of chromosome 8 . There was a small deletion between $12.6 \mathrm{Mb}$ and $13.9 \mathrm{Mb}$, including all of candidate cancer gene DLC1, on an otherwise normal copy of chromosome 8, and a much larger interstitial deletion between 14.2 $\mathrm{Mb}$ and $31.5 \mathrm{Mb}$ on a del(8)(8p12-22). Hybridisation of flow-sorted $\operatorname{del}(8)(8 \mathrm{p} 12-22)$ to the fosmid array pinpointed the distal edge of the deletion to between $14.19 \mathrm{Mb}$ and $14.24 \mathrm{Mb}$, within the gene SGCZ (Figure 3a).

Overall DLC1, the most well characterised tumour suppressor candidate in 8 p22, was only affected in a single cell line by a copy number decrease that included two other genes. This result is perhaps not surprising as it is known that DLC1 expression does not correlate with copy number [39] and, in several tumour types, down-regulation is caused by promoter methylation [40]. In support of this, DLC1 expression was decreased in $62 \%$ (8/13) cell lines analysed by quantitative PCR, including four lines without detectable genomic changes in this region (Figure $3 c)$.

In contrast, TUSC3 was affected by two small deletions that did not include any other gene. TUSC3 showed decreased expression in these two lines with deletions but not in any other line (Figure 3c). Anecdotally, TUSC3 also showed decreased expression in a panel of 61 primary breast tumours (Figure 3d). This identified six tumours that had completely lost expression of TUSC3, and a further thirteen that expressed it at a lower level than the range observed in normal breast luminal and basal cells.

Neither the 5' nor the 3' end of SGCZ showed expression in the lines with copy number changes within it (HCC1187, SUM44), or model normal breast line HB4a (results not shown), so it is neither a likely target of dele- 


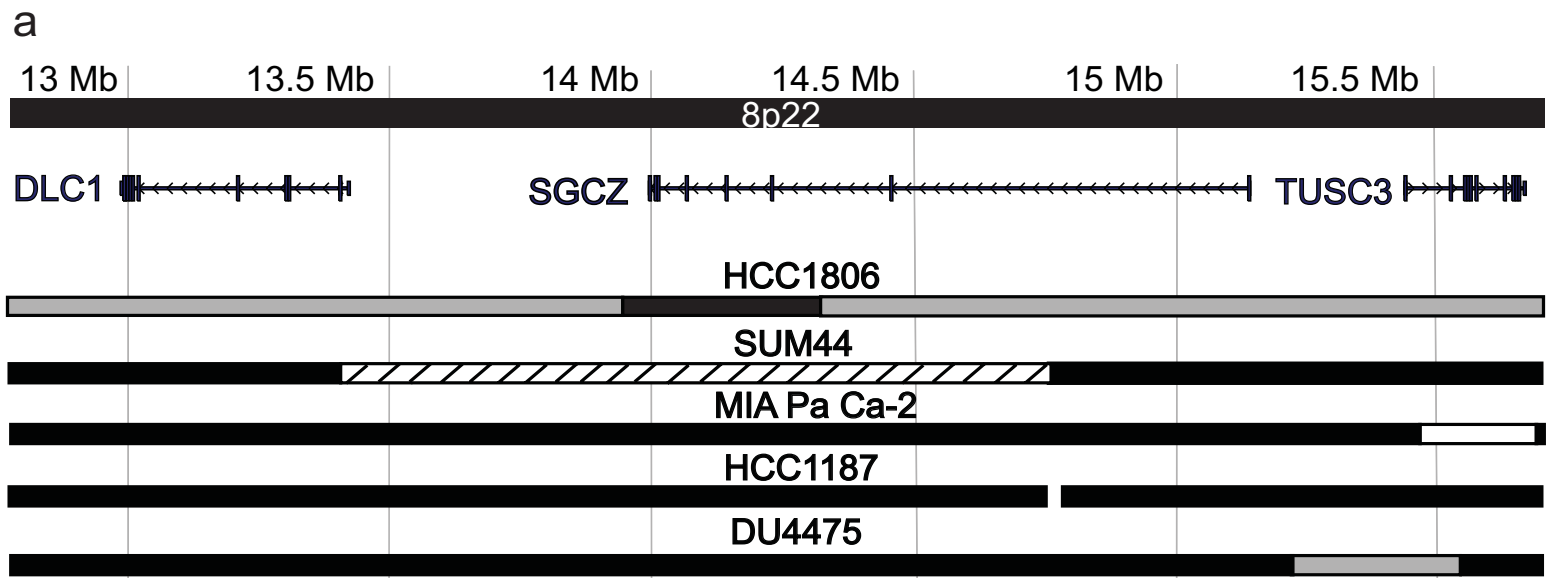

b

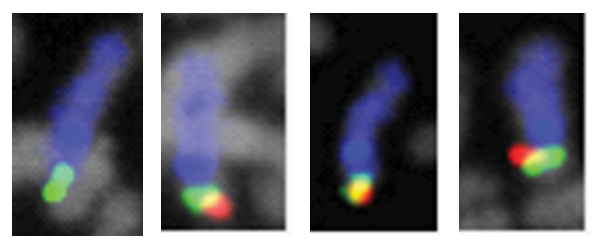

d

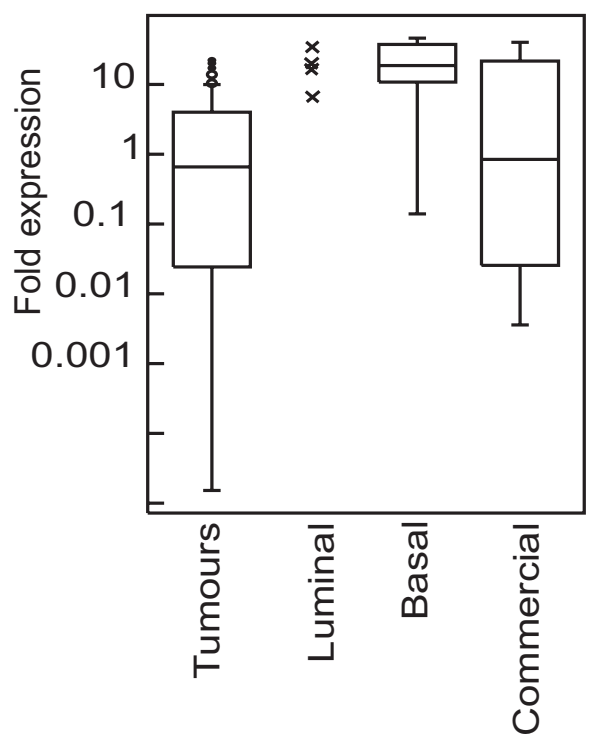

C

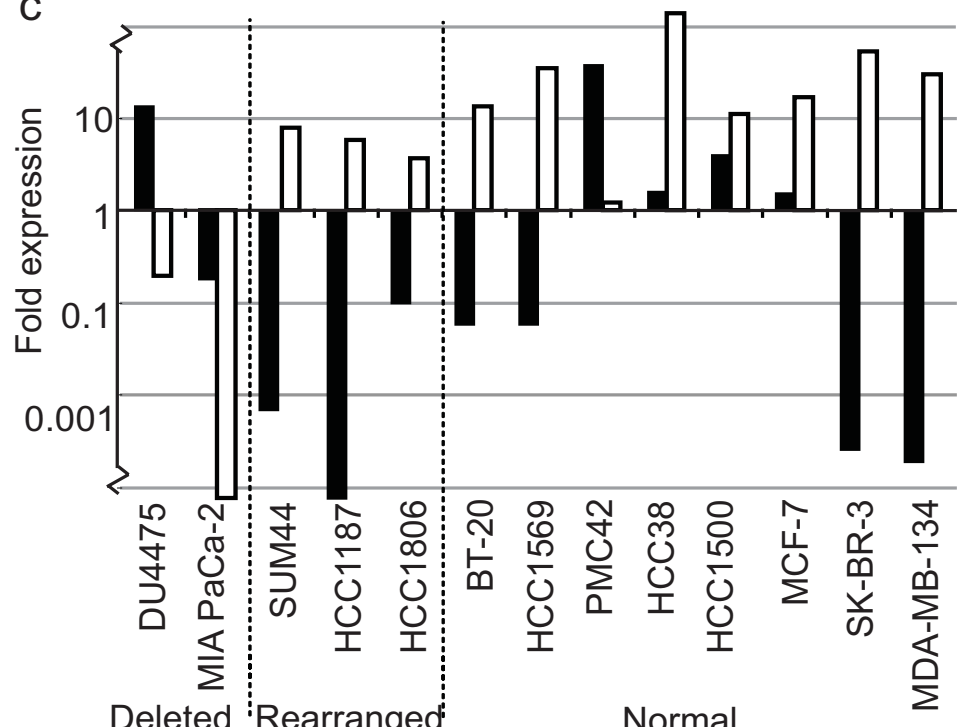

Figure 3

Analysis of 8p22 rearrangements. (a) Rearrangements between $12.9 \mathrm{Mb}$ and $15.6 \mathrm{Mb}$ in 8p22. Black bar, normal copy number for 8p; Grey, heterozygous loss; White with black outline, homozygous loss; White with no outline, breakpoint of reciprocal translocation; Black hatching, gain. (b) FISH showing the deletion of the TUSC3 promoter on one of the four copies of chromosome 8 in DU4475. Blue, chromosome 8 paint; Green, RPI I-480MI8 (I5.0 Mb); Red, RPI I-3 I4PIO (I5.6 Mb). (c) DLCI (black bars) and TUSC3 (white bars) expression levels relative to normal breast line HB4a. Note TUSC3 expression is decreased in MIA PaCa-2 and DU4475, the two cell lines with deletions of this gene. (d) TUSC3 expression in primary breast tumours and various normal breast samples (see Methods). TUSC3 expression is lower in a subset of tumours than in any control group. 
tion nor of activation or inactivation by the translocation or insertion breakpoints.

\section{Loss of $8 p 23.3$}

Six cell lines showed losses close to the telomere, within 8 p23, all including a minimum common region of deletion from $1.7 \mathrm{Mb}$ to $1.9 \mathrm{Mb}$ (Figure 4a). PMC42, HCC38 and HCC1569 had losses from the telomere to $2.2 \mathrm{Mb}$, 3.4 $\mathrm{Mb}$ and $3.7 \mathrm{Mb}$ respectively; HCC1500 had a deletion between $1.3 \mathrm{Mb}$ and $36.5 \mathrm{Mb}$; DU4475 had a heterozygous deletion between 1.1 $\mathrm{Mb}$ and 1.9 $\mathrm{Mb}$ and MIA PaCa-2 had a homozygous deletion between 1.7 Mb and $1.9 \mathrm{Mb}$, first reported by Bashyam et al. ([4]. In order to identify the genes affected by the minimum common region of loss, the homozygous deletion in MIA PaCa-2 was mapped by PCR. It included exon three, but not exon 2 of CLN8, and all of C8orf61, ARHGEF10 and micro RNA hsa-mir-596 (Figure 4a).

Since DU4475 had a heterozygous deletion, in order to fit the classical model of a tumour suppressor gene, we would expect the remaining copy of the target gene to be disrupted by some other mechanism, such as point mutation, in this line. Expression data for multiple cancer cell lines (not shown) suggested ARHGEF10 as a more likely target gene than $C L N 8$, since ARHGEF10 expression was decreased by more than $50 \%$ in $83 \%(15 / 18)$ of lines tested. We therefore sequenced ARHGEF10 in DU4475 and found a $\mathrm{C} \rightarrow \mathrm{T}$ point mutation in exon 19 (Figure 4b). This causes a non-conservative histidine to tyrosine substitution in the protein product at position 733, a highly conserved region (Figure 4c). Although paired normal DNA is not available for this cell line this nucleotide change is not listed as a known SNP (single nucleotide polymorphism) in the Entrez SNP database (Build 129).

The breast cancer cell line DU4475 was unique in having five separate small deletions on 8p (Additional file 5), at least three of which coincided with candidate tumour suppressor genes: a deletion of the promoter of candidate tumour suppressor TUSC3 (Tumour Suppressor Candidate 3) $(15.6 \mathrm{Mb})$ in $8 \mathrm{p} 22$, an approximately $1 \mathrm{Mb}$ deletion between $21.9 \mathrm{Mb}$ and $23.0 \mathrm{Mb}$ in $8 \mathrm{p} 21$, containing candidate cancer genes RHOBTB2 (22.9 Mb) and DR5 (Death receptor 5$)(23.0 \mathrm{Mb})[41]$ but not extending as far as DR4, and a deletion in 8p23.3, which emerged as a common region of loss in this study.

\section{Discussion}

This high-resolution array CGH study of $8 \mathrm{p}$ in carcinomas has allowed us to build a picture of the more distal events on $8 \mathrm{p}$ and to put each change into context. Previous array CGH studies have focused on 8p11-12 as a site of recurrent translocation and amplification $[10,11,14,17,19]$. We now present a high-resolution dataset for the whole of
$8 p$ with specific follow-up of recurrent events occurring on distal $8 \mathrm{p}-$ a relatively unstudied $30 \mathrm{Mb}$ of DNA.

We identified three novel regions of interest on distal 8p: $8 \mathrm{p} 21.3$, which contained a novel amplicon centred at $21.8 \mathrm{Mb} ; 8 \mathrm{p} 22$, which had a variety of rearrangements between $12.9 \mathrm{Mb}$ and $15.6 \mathrm{Mb}$; and a region of consistent loss centred at $1.8 \mathrm{Mb}$ in $8 \mathrm{p} 23.3$. These results show that high-resolution BAC array CGH is a good approach for characterising genomic rearrangements to a resolution that provides a manageable number of candidate genes for further study in a cost-effective way.

\section{Amplification around $21.8 \mathrm{Mb}$ in $8 \mathrm{p} 21.3$}

A novel amplicon was found in 8p21.3 in both cell lines and primary tumours. Amplification was a relatively rare event, seen in $6 \%(2 / 41)$ of cell lines and $1 / 98$ primary tumours, perhaps due to the reported over-representation of tumours with amplicons in the cell line collection [19]. However, the presence of the amplicon in primary tumour material confirms it as a genuine event in breast cancer. Furthermore, the minimum region of amplification contains candidate genes from families known to play a role in carcinogenesis.

FGF17 (fibroblast growth factor 17) is a member of the fibroblast growth factor family, a group strongly implicated in carcinogenesis. FGF pathway genes, including FGF3, FGF4 and FGF8, are common targets of MMTV integration $[42,43]$ and FGFR3 mutations have been reported in $41 \%$ of bladder cancers [44]. FGF17 is upregulated in some prostate cancers and this correlates with a higher risk of metastases and lower survival [45]. NPM2 (Nucleophosmin/nucleoplasmin member 2) can catalyse the assembly of DNA and histones into nucleosomes and is involved in decondensation and remodelling of sperm chromatin immediately after fertilisation. In the same family, NPM1 has the ability to regulate the function of the tumour suppressor protein ARF [46], and is mutated in several haematological malignancies including $35 \%$ of acute myeloid leukaemias $[47,48]$. GFRA2 mediates RET signalling in response to the ligand GDNF [49]. RET is a well-known oncogene that plays a role in the development of thyroid carcinomas and the familial cancer syndrome multiple endocrine neoplasia (reviewed in [50]).

Of these genes FGF17 and NPM2 showed over-expression in two cell lines, one with (MDA-MB-134), and one without (DU4475), amplification. However, neither was overexpressed in the second cell line with amplification in this region (BT-20). If, as the array CGH data suggests, the highest level of amplification in BT-20 lies outside the region amplified in MDA-MB-134, there may be multiple targets of amplification in this region. A similarly complex pattern of non-overlapping amplicon peaks is seen in 


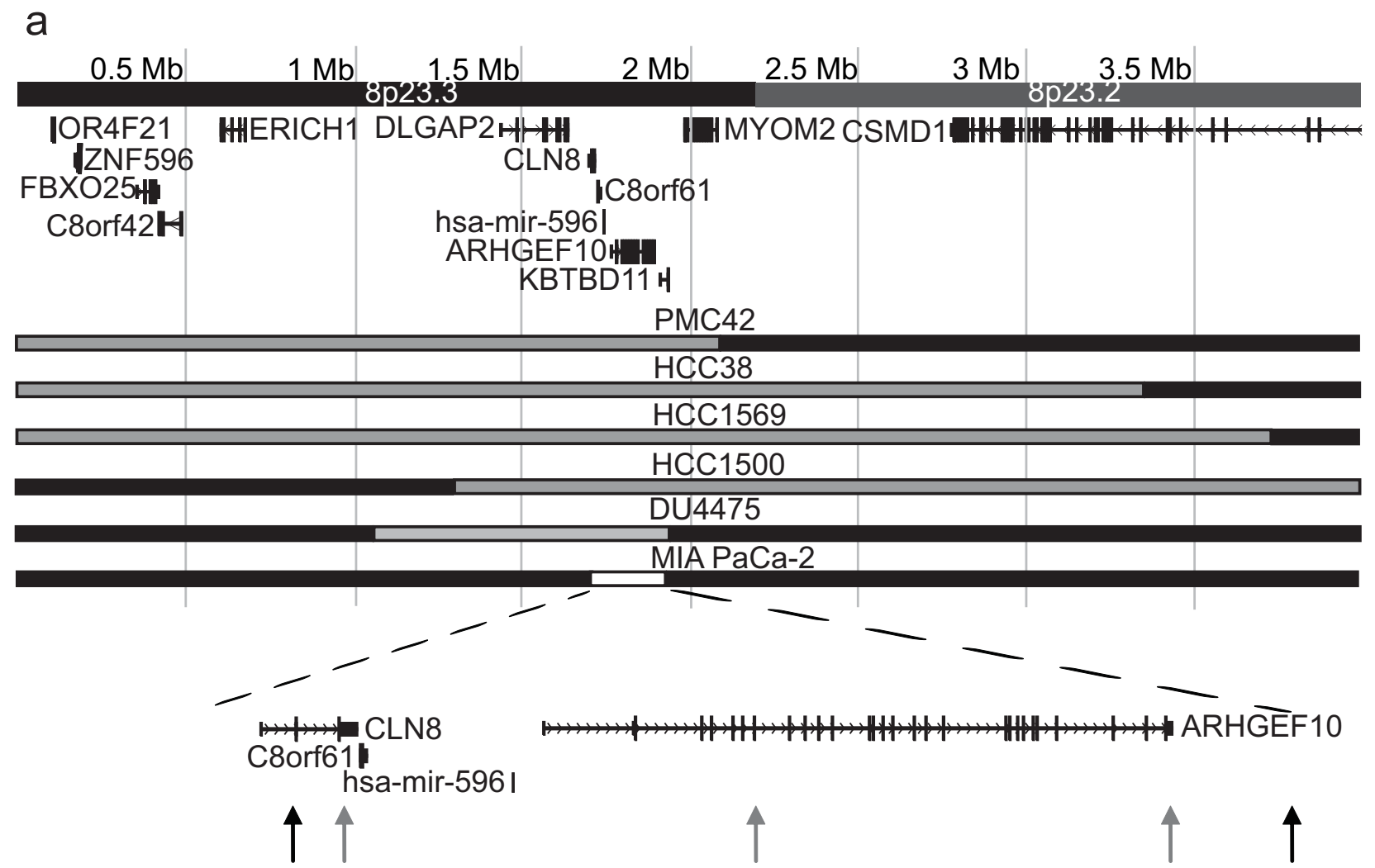

b

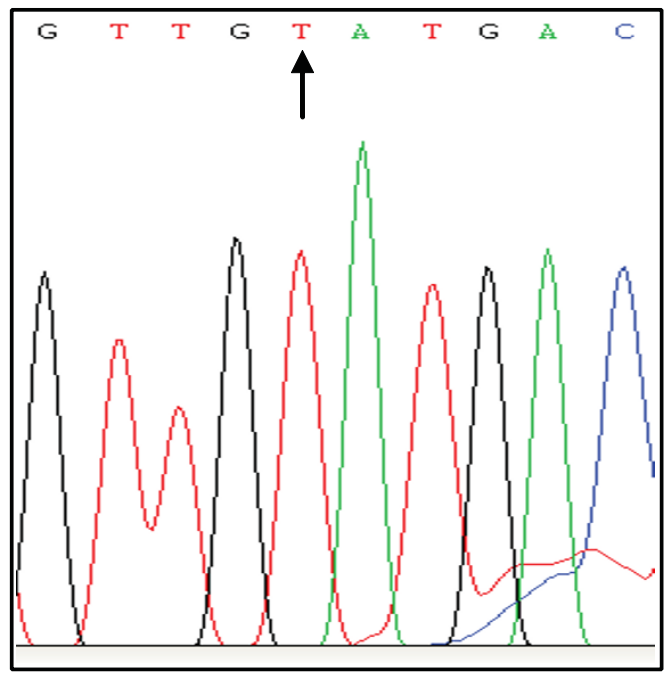

C

Homo sapiens

Pan troglodytes

Bos taurus

Mus musculus

Rattus norvegicus

Canis familiaris

Xenopus tropicalis

Gallus gallus
GQLYQDLQNLL HDLNVIGQITQL GQLYQDLQNLL HDLNVIGQITQL GQLYQDLQNLL HDLSVIGHITQL GQLYQDLQNLL HDLNVVGQISQL GQLYQDLQNLL HDLNVVGQISQL GQLYQDLQNLL HDLNVVGQISQL GQLYQDLQNLL HDLNVVGQISQL GQLYHDLQNLL HDLNVVGQISQL

\section{Figure 4}

Analysis of losses in 8p23.3. (a) Losses between 3.7 Mb and the telomere. Black bar, normal copy number for 8p; Grey, heterozygous loss; White with black outline, homozygous loss. Black arrows, position of primer pairs that amplify a product from MIA PaCa-2 genomic DNA i.e. lie outside the homozygous deletion; Grey arrows, position of primer pairs that do not amplify a product from MIA PaCa-2 genomic DNA. (b) Sequencing trace showing the point mutation in exon 19 of

ARHGEFI0. The normal sequence has a cytosine at the position indicated by the arrow. (c) Conservation of ARHGEFI0. Yellow, the residue that is converted from a histidine to tyrosine by the point mutation in DU4475; Grey, conserved residues. 
$8 \mathrm{p} 12$ and $11 \mathrm{q} 13$ in breast cancer, and has led to the suggestion that they contain as many as four targets $[11,51]$.

\section{Rearrangements between $12.9 \mathrm{Mb}$ and $15.6 \mathrm{Mb}$ in $8 \mathrm{p} 22$}

SGCZ (14.6 Mb), although disrupted by two unbalanced changes and one balanced translocation breakpoint, is unlikely to be a cancer gene. It forms part of the sarcoglycan complex that links the intracellular cytoskeleton to the extracellular matrix in muscle [52], and our findings show that it is not expressed, either in normal breast or as a consequence of rearrangement. Although DLC1 (13.2 $\mathrm{Mb}$ ) has a tumour suppressive effect in a variety of tumour types, including breast cancer (e.g. [40]), it was not a likely target of these $8 \mathrm{p} 22$ rearrangements as it lay just outside the rearrangements in all except one case. This is consistent with suggestions that genomic rearrangement is not a mechanism of DLC1 inactivation [39]. If a tumour suppressor gene is present in this region, then TUSC3 $(15.6 \mathrm{Mb})$, previously suggested as a potential target in this region $([4,53,54]$, was the strongest candidate target of the rearrangements of 8 p22 in this study. Two cell lines have deletions that solely affect TUSC3 and result in decreased expression and expression was lost or decreased in $31 \%$ of primary breast tumours. However, the presence of several breakpoints in this region that do not appear to have an effect at the gene level could alternatively suggest that this site is prone to breakage.

\section{Losses between I.0 Mb and 2.I Mb in 8p23.3}

Loss of $8 \mathrm{p} 23.3$, with a minimum common region of between $1.7 \mathrm{Mb}$ and $1.9 \mathrm{Mb}$, was found in both breast and pancreatic cell lines, consistent with evidence from $\mathrm{LOH}$ studies of a cancer gene situated between $1.0 \mathrm{Mb}$ and 2.1 Mb. $1 \mathrm{Mb}$ array CGH data [55] from primary breast tumours suggests that $8 \mathrm{p} 23.3$ is a genuine target in primary tumours. $8 \%(6 / 73)$ of tumours may have specific loss distal to $10 \mathrm{Mb}$. However, analysis of that dataset is difficult due to the low resolution and the effect of contaminating normal DNA on $\log _{2}$ ratio shifts in primary material. In combination, these results suggest the region between $1.0 \mathrm{Mb}$ and $2.1 \mathrm{Mb}$ as the location of a tumour suppressor gene. The genes affected by the minimum common region of deletion, and therefore candidates, are CLN8, C8orf61, has-mir-596 and ARHGEF10. ARHGEF10 has emerged as a candidate colorectal cancer gene in the sequencing screen carried out by Wood et al. [56], and, in conjunction with our discovery of a heterozygous deletion of ARHGEF10 in DU4475 with mutation of the remaining copy, this makes it a strong candidate for the 8p23.3 tumour suppressor. Functional data about ARHGEF10 supports a role for it in carcinogenesis. It activates RhoB [57], which is down-regulated in multiple tumour types $[58,59]$ and is necessary for apoptosis in response to DNA damage in transformed cells [60].

\section{A parsimonious model to explain $8 p$ rearrangements}

A large number of cancers lose all, or nearly all of $8 p$, potentially suggesting the presence of tumour suppressor loci, while the occurrence of specific rearrangements on distal $8 \mathrm{p}$ supports the theory that there are multiple cancer genes located on 8p. Many previous LOH and copy number studies, as well as our data, especially the specificity of the deletions in DU4475, can narrow down the regions of loss to $8 \mathrm{p} 22$ and $8 \mathrm{p} 23$; we suggest TUSC3 and ARHGEF10 as possible targets of genomic rearrangement. There may well be other tumour suppressor genes, such as $D L C 1$, located on $8 \mathrm{p}$ but these appear to be inactivated by alternative mechanisms, including methylation. These results lead us to suggest a parsimonious model to explain the varied rearrangements seen on $8 \mathrm{p}$ in cancer (Figure 5)

The most frequent rearrangements are loss of distal $8 p$, from $8 \mathrm{p} 12$ to the telomere, sometimes with proximal amplification of 8p11-12. As previously suggested, unbalanced translocations through 8p11-12 can be explained by the presence of a major tumour suppressor gene at the most distal of these breaks, around $30 \mathrm{Mb}[10]$. However, we argue that if this were the only tumour suppressor gene on $8 \mathrm{p}$, we might expect to see a mirror-image pattern of breaks distal to this gene with the telomeric sequences being retained, as well as interstitial deletions of the tumour suppressor gene. A tendency towards loss of the whole of distal $8 p$ suggests that there is at least one further tumour suppressor gene, and that it is located close to the telomere (Figure 5). This is consistent with our data suggesting a tumour suppressor gene is located in 8p23.3. There can therefore also be any number of additional tumour suppressor genes in between these two which would give the same pattern of rearrangement, and our data suggests that there may be at least one further candidate gene located in 8 p22. In line with the application of Occam's razor loss of both/all of these tumour suppressor genes is most often seen as loss of the whole of distal $8 p$, but can also be achieved by several more specific events, therefore explaining the complex and inconsistent pattern of changes on distal 8p (Figure 5) - tumours may have deletions of varying sizes encompassing two or more tumour suppressor genes as well as losing them all by loss of the whole of $8 \mathrm{p}$ or a proximal translocation.

Cell lines with multiple small deletions are invaluable in allowing us to narrow down the number and position of tumour suppressor genes on $8 \mathrm{p}$. The unique pattern of deletions in DU4475, three of which target candidate tumour suppressor genes or regions previously reported as frequently deleted, supports $8 \mathrm{p} 23.3,8 \mathrm{p} 22$ and $8 \mathrm{p} 21$ as candidate regions. Potential targets in $8 \mathrm{p} 23.3$ and $8 \mathrm{p} 22$ have been discussed above while 8p21, although only affected by a single small deletion in this study, is the location of RHOBTB2, a candidate breast cancer gene based 
on the discovery of two somatic mutations [41], and the TRAIL receptors DR4 and DR5, which have been suggested as candidate cancer genes owing to their pro-apoptotic function [61]. MIA PaCa-2 has two deletions on 8p, also supporting the existence of tumour suppressor genes at $8 \mathrm{p} 22$ and 8p23.3.

Although the premise of our Discussion is that the driving force behind $8 \mathrm{p}$ rearrangements is selection for the alteration of cancer genes, the same pattern of rearrangements might be observed if the driving force was the mechanism of breakage e.g the presence of fragile sites on $8 \mathrm{p}$. For example, the breaks at 8p12 with proximal amplification could be due to the presence of a fragile site that initiates breakage-fusion-bridge cycles [62] although no fragile site has been shown to exist on 8p [63] and 8p12 breaks frequently occur without accompanying amplification.

\section{Conclusion}

While early work on $8 \mathrm{p}$, driven by LOH analysis [6,7] focused on distal $8 \mathrm{p}$, more recent studies have concentrated on 8p11-12 [10,11] in an attempt to explain the role of this chromosome arm in cancer. This present study suggests that, in addition to the frequently observed loss from 8 p12 to the telomere with proximal amplification, there are additional rarer events that occur on distal 8p. While loss of specific distal loci may occur in only a few cases, loss of these distal sequences may also add to selection for general distal loss following the commonly observed breakage at 8p12 in many tumours.

\section{Competing interests}

The authors declare that they have no competing interests.

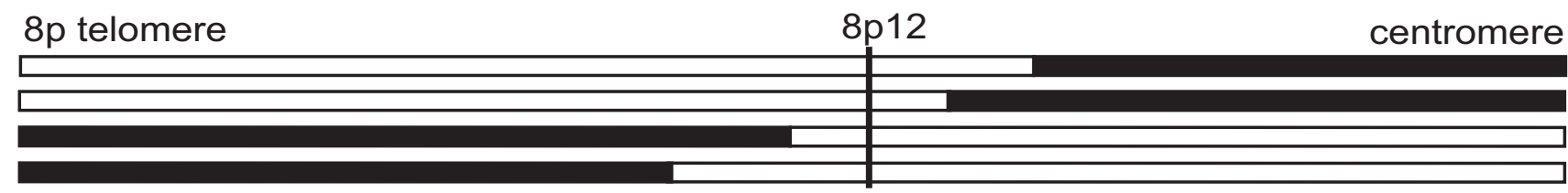

TSG
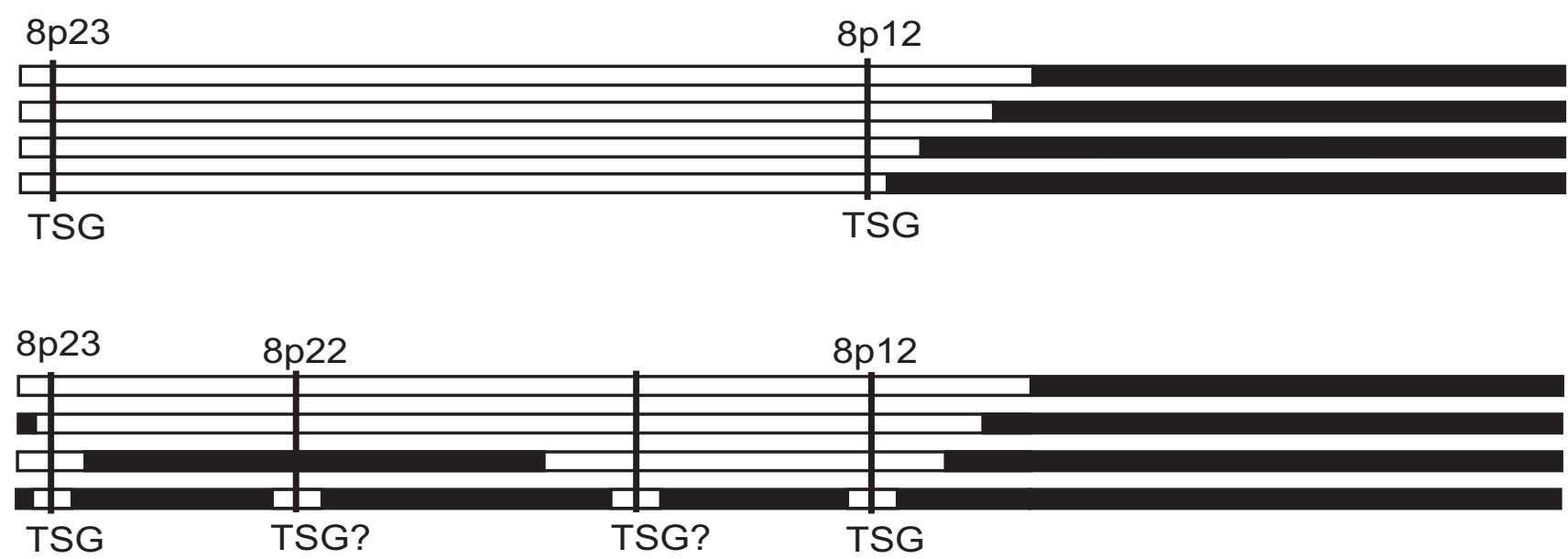

\section{Figure 5}

A parsimonious model of $8 p$ rearrangements. The different patterns of $8 p$ rearrangement that would be expected in a sample of tumours based on the number and position of tumour suppressor genes (not to scale). Top is the pattern of rearrangements expected if there is a single tumour suppressor gene located in $8 \mathrm{p} / 2$. Middle is the pattern of rearrangements predicted if there were at least two tumour suppressor genes located on $8 \mathrm{p}$, one in $8 \mathrm{p} / 2$ and one located close to the telomere in 8p23.3. This fits the common overall pattern of breaks in $8 \mathrm{p} / 2$ with loss of distal 8p. Bottom is a representation of some of the atypical 8p rearrangements found in cancer cell lines including DU4475, HCCI500 and PMC42. These can be explained by the presence of other tumour suppressor genes in between those in 8p 12 and 8p23.3; our results suggest at least one, at 8p22. Since each of these tumour suppressor genes is only lost in a proportion of cases a complex pattern of rearrangements encompassing some or all of these regions results. Loss of the whole of distal $8 p$ will be the most common rearrangement as it removes all tumour suppressor genes as the result of a single event. 


\section{Authors' contributions}

SLC wrote the manuscript and carried out most of the experimental work. JP supervised the experimental work. SFC performed tissue microarray experiments under the supervision of CC. IOE produced the tissue microarrays. PAWE is the research group leader and supervised manuscript writing.

\section{Additional material}

\section{Additional File 1}

Cancer cell lines. This file contains Table 1 - a list of all cancer cell lines used in the study, culture conditions and source.

Click here for file

[http://www.biomedcentral.com/content/supplementary/14712407-8-288-S1.pdf]

\section{Additional File 2}

Validation of $8 p$ array $C G H$. This file includes the array plot for hybridisation of T47D against normal female on the $8 p$ array platform and FISH validation of the normal copy number polymorphism in $8 p 23$. Click here for file

[http://www.biomedcentral.com/content/supplementary/14712407-8-288-S2.pdf]

\section{Additional File 3}

Primers. This file contains Table 2 - a list of the sequences of all primers used in the study.

Click here for file

[http://www.biomedcentral.com/content/supplementary/14712407-8-288-S3.pdf]

\section{Additional File 4}

$8 p$ array CGH. This file includes the data for 38 cancer cell lines for which array CGH was performed on the short arm of chromosome 8. Click here for file

[http://www.biomedcentral.com/content/supplementary/14712407-8-288-S4.xls]

\section{Additional File 5}

Copy number changes on $8 p$. This file contains Table 3 - a summary of all the copy number changes on $8 p$ identified by array CGH in 38 cancer cell lines.

Click here for file

[http://www.biomedcentral.com/content/supplementary/14712407-8-288-S5.pdf]

\section{Additional File 6}

Fosmid array CGH. This file includes the fosmid array CGH data for cell lines with rearrangements in either $8 p 23.3$ or $8 p 22$, between DLC1 and TUSC3.

Click here for file

[http://www.biomedcentral.com/content/supplementary/14712407-8-288-S6.xls]

\section{Acknowledgements}

We thank Rachel Lyman for help with cell culture and metaphase preparation, Dr Karen Howarth and Patricia O'Brien for providing sorted chromo- somes, Professor Mike O'Hare for providing cells, Sarah Hyland for assistance with sequencing, and Dr Cherie Blenkiron and Dr Yii Leng Chua for tumour RNA extraction and reverse transcription. The arrays were printed by Dr Anthony Brown at the University of Cambridge, Department of Pathology, Centre for Microarray resources. Research is supported by CRUK, Breast Cancer Campaign, BBSRC and MRC (studentship for SLC).

\section{References}

I. Tirkkonen M, Tanner M, Karhu R, Kallioniemi A, Isola J, Kallioniemi OP: Molecular cytogenetics of primary breast cancer by CGH. Genes Chromosomes Cancer 1998, 21:177-184.

2. Loo LW, Grove DI, Williams EM, Neal CL, Cousens LA, Schubert EL, Holcomb IN, Massa HF, Glogovac J, Li Cl, Malone KE, Daling JR, Delrow JJ, Trask BJ, Hsu L, Porter PL: Array comparative genomic hybridization analysis of genomic alterations in breast cancer subtypes. Cancer Res 2004, 64:854I-8549.

3. Davidson JM, Gorringe KL, Chin SF, Orsetti B, Besret C, CourtayCahen C, Roberts I, Theillet C, Caldas C, Edwards PA: Molecular cytogenetic analysis of breast cancer cell lines. $\mathrm{Br} J$ Cancer 2000, 83: I309-1317.

4. Bashyam MD, Bair R, Kim YH, Wang P, Hernandez-Boussard T, Karikari CA, Tibshirani R, Maitra A, Pollack JR: Array-based comparative genomic hybridization identifies localized DNA amplifications and homozygous deletions in pancreatic cancer. Neoplasia 2005, 7:556-562.

5. Emi M, Fujiwara $Y$, Nakajima T, Tsuchiya E, Tsuda H, Hirohashi S, Maeda Y, Tsuruta K, Miyaki M, Nakamura Y: Frequent loss of heterozygosity for loci on chromosome $8 p$ in hepatocellular carcinoma, colorectal cancer, and lung cancer. Cancer Res 1992, 52:5368-5372.

6. Wu CL, Roz L, Sloan P, Read AP, Holland S, Porter S, Scully C, Speight $P M$, Thakker N: Deletion mapping defines three discrete areas of allelic imbalance on chromosome arm $8 p$ in oral and oropharyngeal squamous cell carcinomas. Genes Chromosomes Cancer 1997, 20:347-353.

7. Wright K, Wilson PJ, Kerr J, Do K, Hurst T, Khoo SK, Ward B, Chenevix-Trench G: Frequent loss of heterozygosity and three critical regions on the short arm of chromosome 8 in ovarian adenocarcinomas. Oncogene 1998, 17:1185-1188.

8. Muscheck M, Sukosd F, Pesti T, Kovacs G: High density deletion mapping of bladder cancer localizes the putative tumor suppressor gene between loci D8S504 and D8S264 at chromosome 8p23.3. Lab Invest 2000, 80:1089-1093.

9. Thompson F, Emerson J, Dalton W, Yang JM, McGee D, Villar H, Knox S, Massey K, Weinstein R, Bhattacharyya A, et al.: Clonal chromosome abnormalities in human breast carcinomas. I. Twenty-eight cases with primary disease. Genes Chromosomes Cancer 1993, 7: 185-193.

10. Pole JC, Courtay-Cahen C, Garcia MJ, Blood KA, Cooke SL, Alsop AE, Tse DM, Caldas C, Edwards PA: High-resolution analysis of chromosome rearrangements on $8 \mathrm{p}$ in breast, colon and pancreatic cancer reveals a complex pattern of loss, gain and translocation. Oncogene 2006, 25:5693-5706.

II. Gelsi-Boyer V, Orsetti B, Cervera N, Finetti P, Sircoulomb F, Rouge C, Lasorsa L, Letessier A, Ginestier C, Monville F, Esteyries S, Adelaide J, Esterni B, Henry C, Ethier SP, Bibeau F, Mozziconacci MJ, Charafe-Jauffret E, Jacquemier J, Bertucci F, Birnbaum D, Theillet C, Chaffanet M: Comprehensive profiling of 8p II-12 amplification in breast cancer. Mol Cancer Res 2005, 3:655-667.

12. Adelaide J, Huang HE, Murati A, Alsop AE, Orsetti B, Mozziconacci MJ, Popovici C, Ginestier C, Letessier A, Basset C, Courtay-Cahen C, jacquemier J, Theillet C, Birnbaum D, Edwards PA, Chaffanet M: A recurrent chromosome translocation breakpoint in breast and pancreatic cancer cell lines targets the neuregulin/NRG I gene. Genes Chromosomes Cancer 2003, 37:333-345.

13. Prentice LM, Shadeo A, Lestou VS, Miller MA, deLeeuw RJ, Makretsov $\mathrm{N}$, Turbin D, Brown LA, Macpherson N, Yorida E, Cheang MC, Bentley J, Chia S, Nielsen TO, Gilks CB, Lam W, Huntsman DG: NRGI gene rearrangements in clinical breast cancer: identification of an adjacent novel amplicon associated with poor prognosis. Oncogene 2005, 24:728I-7289.

14. Garcia MJ, Pole JC, Chin SF, Teschendorff A, Naderi A, Ozdag H, Vias M, Kranjac T, Subkhankulova T, Paish C, Ellis I, Brenton JD, Edwards PA, Caldas C: A I Mb minimal amplicon at 8p II-I2 in breast 
cancer identifies new candidate oncogenes. Oncogene 2005, 24:5235-5245.

15. Ray ME, Yang ZQ, Albertson D, Kleer CG, Washburn JG, Macoska JA, Ethier SP: Genomic and expression analysis of the 8p I I-I 2 amplicon in human breast cancer cell lines. Cancer Res 2004, 64:40-47.

16. Adnane J, Gaudray P, Dionne CA, Crumley G, Jaye M, Schlessinger J, Jeanteur $P$, Birnbaum D, Theillet C: BEK and FLG, two receptors to members of the FGF family, are amplified in subsets of human breast cancers. Oncogene |99|, 6:659-663.

17. Paterson AL, Pole JC, Blood KA, Garcia MJ, Cooke SL, Teschendorff AE, Wang Y, Chin SF, Ylstra B, Caldas C, Edwards PA: Co-amplification of $8 \mathrm{pl} 2$ and $\mathrm{IIqI} 3$ in breast cancers is not the result of a single genomic event. Genes Chromosomes Cancer 2007, 46:427-439.

18. Still IH, Hamilton M, Vince P, Wolfman A, Cowell JK: Cloning of TACCI, an embryonically expressed, potentially transforming coiled coil containing gene, from the $8 \mathrm{p} \mathrm{I} \mathrm{I} \mathrm{breast} \mathrm{cancer}$ amplicon. Oncogene 1999, 18:4032-4038.

19. Neve RM, Chin K, Fridlyand J, Yeh J, Baehner FL, Fevr T, Clark L, Bayani N, Coppe JP, Tong F, Speed T, Spellman PT, DeVries S, Lapuk A, Wang NJ, Kuo WL, Stilwell JL, Pinkel D, Albertson DG, Waldman FM, McCormick F, Dickson RB, Johnson MD, Lippman M, Ethier S, Gazdar A, Gray JW: A collection of breast cancer cell lines for the study of functionally distinct cancer subtypes. Cancer Cell 2006, 10:515-527.

20. Heidenblad M, Schoenmakers EF, Jonson T, Gorunova L, Veltman JA, van Kessel AG, Hoglund M: Genome-wide array-based comparative genomic hybridization reveals multiple amplification targets and novel homozygous deletions in pancreatic carcinoma cell lines. Cancer Res 2004, 64:3052-3059.

21. Shadeo A, Lam WL: Comprehensive copy number profiles of breast cancer cell model genomes. Breast Cancer Res 2006, 8:R9

22. Jonsson G, Staaf J, Olsson E, Heidenblad M, Vallon-Christersson J Osoegawa K, de Jong P, Oredsson S, Ringner M, Hoglund M, Borg A: High-resolution genomic profiles of breast cancer cell lines assessed by tiling BAC array comparative genomic hybridization. Genes Chromosomes Cancer 2007, 46:543-558.

23. Sjoblom T, Jones S, Wood LD, Parsons DW, Lin J, Barber TD, Mandelker D, Leary RJ, Ptak J, Silliman N, Szabo S, Buckhaults P, Farrell C, Meeh P, Markowitz SD, Willis J, Dawson D, Willson JK, Gazdar AF, Hartigan J, Wu L, Liu C, Parmigiani G, Park BH, Bachman KE, Papadopoulos N, Vogelstein B, Kinzler KW, Velculescu VE: The consensus coding sequences of human breast and colorectal cancers. Science 2006, 3 | 4:268-274.

24. Stamps AC, Davies SC, Burman J, O'Hare MJ: Analysis of proviral integration in human mammary epithelial cell lines immortalized by retroviral infection with a temperature-sensitive SV40 T-antigen construct. Int J Cancer 1994, 57:865-874.

25. Elston CW, Ellis IO: Pathological prognostic factors in breast cancer. I. The value of histological grade in breast cancer: experience from a large study with long-term follow-up. Histopathology 1991, 19:403-410.

26. Parker C, Rampaul RS, Pinder SE, Bell JA, Wencyk PM, Blamey RW, Nicholson RI, Robertson JF: E-cadherin as a prognostic indicator in primary breast cancer. $\mathrm{Br} /$ Cancer 2001, 85:1958-1963.

27. Chin SF, Teschendorff AE, Marioni JC, Wang Y, Barbosa-Morais NL, Thorne NP, Costa JL, Pinder SE, Wiel MA van de, Green AR, Ellis IO Porter PL, Tavare S, Brenton JD, Ylstra B, Caldas C: High-resolution aCGH and expression profiling identifies a novel genomic subtype of ER negative breast cancer. Genome Biol 2007, 8:R2I5

28. Chin SF, Wang Y, Thorne NP, Teschendorff AE, Pinder SE, Vias M, Naderi A, Roberts I, Barbosa-Morais NL, Garcia MJ, lyer NG, Kranjac T, Robertson JF, Aparicio S, Tavare S, Ellis I, Brenton JD, Caldas C: Using array-comparative genomic hybridization to define molecular portraits of primary breast cancers. Oncogene 2007 , 26:1959-1970.

29. Callagy GM, Pharoah PD, Pinder SE, Hsu FD, Nielsen TO, Ragaz J, Ellis $\mathrm{IO}$, Huntsman $\mathrm{D}$, Caldas $\mathrm{C}: \mathbf{B c l}-\mathbf{2}$ is a prognostic marker in breast cancer independently of the Nottingham Prognostic Index. Clin Cancer Res 2006, I 2:2468-2475.

30. Krzywinski M, Bosdet I, Smailus D, Chiu R, Mathewson C, Wye N, Barber S, Brown-John M, Chan S, Chand S, Cloutier A, Girn N, Lee D, Masson A, Mayo M, Olson T, Pandoh P, Prabhu AL, Schoenmakers E, Tsai M, Albertson D, Lam W, Choy CO, Osoegawa K, Zhao S, de
Jong PJ, Schein J, Jones S, Marra MA: A set of BAC clones spanning the human genome. Nucleic Acids Res 2004, 32:365I-3660.

3I. Fiegler H, Carr P, Douglas EJ, Burford DC, Hunt S, Scott CE, Smith J, Vetrie D, Gorman P, Tomlinson IP, Carter NP: DNA microarrays for comparative genomic hybridization based on DOP-PCR amplification of BAC and PAC clones. Genes Chromosomes Cancer 2003, 36:36I-374.

32. Huang HE, Chin SF, Ginestier C, Bardou VJ, Adelaide J, lyer NG, Garcia MJ, Pole JC, Callagy GM, Hewitt SM, Gullick WJ, Jacquemier J, Caldas C, Chaffanet M, Birnbaum D, Edwards PA: A recurrent chromosome breakpoint in breast cancer at the NRGI/neuregulin I/heregulin gene. Cancer Res 2004, 64:6840-6844.

33. Howarth KD, Blood KA, Ng BL, Beavis JC, Chua Y, Cooke SL, Raby S, Ichimura K, Collins VP, Carter NP, Edwards PA: Array painting reveals a high frequency of balanced translocations in breast cancer cell lines that break in cancer-relevant genes. Oncogene 2007.

34. Alsop $A E$, Teschendorff $A E$, Edwards PA: Distribution of breakpoints on chromosome 18 in breast, colorectal, and pancreatic carcinoma cell lines. Cancer Genet Cytogenet 2006, 164:97-109.

35. Chin SF, Daigo Y, Huang HE, lyer NG, Callagy G, Kranjac T, Gonzalez $M$, Sangan T, Earl H, Caldas C: A simple and reliable pretreatment protocol facilitates fluorescent in situ hybridisation on tissue microarrays of paraffin wax embedded tumour samples. Mol Pathol 2003, 56:275-279.

36. Clarke C, Titley J, Davies S, O'Hare MJ: An immunomagnetic separation method using superparamagnetic (MACS) beads for large-scale purification of human mammary luminal and myoepithelial cells. Epithelial Cell Biol 1994, 3:38-46.

37. Hollox EJ, Armour JA, Barber JC: Extensive normal copy number variation of a beta-defensin antimicrobial-gene cluster. $\mathrm{Am} J$ Hum Genet 2003, 73:591-600.

38. Mars WM, Patmasiriwat P, Maity T, Huff $V$, Weil MM, Saunders GF: Inheritance of unequal numbers of the genes encoding the human neutrophil defensins HP-I and HP-3. J Biol Chem I995, 270:3037|-30376.

39. Plaumann M, Seitz S, Frege R, Estevez-Schwarz L, Scherneck S: Analysis of DLC-I expression in human breast cancer. J Cancer Res Clin Oncol 2003, I 29:349-354.

40. Yuan BZ, Zhou X, Durkin ME, Zimonjic DB, Gumundsdottir K, Eyfjord JE, Thorgeirsson SS, Popescu NC: DLC-I gene inhibits human breast cancer cell growth and in vivo tumorigenicity. Oncogene 2003, 22:445-450.

4I. Hamaguchi M, Meth IL, von Klitzing C, Wei W, Esposito D, Rodgers L, Walsh T, Welcsh P, King MC, Wigler MH: DBC2, a candidate for a tumor suppressor gene involved in breast cancer. Proc Natl Acad Sci USA 2002, 99:13647-13652.

42. Chatterjee G, Rosner A, Han Y, Zelazny ET, Li B, Cardiff RD, Perkins AS: Acceleration of mouse mammary tumor virus-induced murine mammary tumorigenesis by a p53 $172 \mathrm{H}$ transgene: influence of FVB background on tumor latency and identification of novel sites of proviral insertion. Am J Pathol 2002, 161:2241-2253.

43. Theodorou V, Kimm MA, Boer M, Wessels L, Theelen W, Jonkers J, Hilkens J: MMTV insertional mutagenesis identifies genes, gene families and pathways involved in mammary cancer. Nat Genet 2007, 39:759-769.

44. Sibley K, Stern P, Knowles MA: Frequency of fibroblast growth factor receptor 3 mutations in sporadic tumours. Oncogene 200I, 20:44I6-44I8.

45. Heer R, Douglas D, Mathers ME, Robson CN, Leung HY: Fibroblast growth factor 17 is over-expressed in human prostate cancer. J Pathol 2004, 204:578-586.

46. Bertwistle $D$, Sugimoto $M$, Sherr $C$ J: Physical and functional interactions of the Arf tumor suppressor protein with nucleophosmin/B23. Mol Cell Biol 2004, 24:985-996.

47. Falini B, Mecucci C, Tiacci E, Alcalay M, Rosati R, Pasqualucci L, La Starza R, Diverio D, Colombo E, Santucci A, Bigerna B, Pacini R, Pucciarini A, Liso A, Vignetti M, Fazi P, Meani N, Pettirossi V, Saglio G, Mandelli F, Lo-Coco F, Pelicci PG, Martelli MF: Cytoplasmic nucleophosmin in acute myelogenous leukemia with a normal karyotype. N Engl J Med 2005, 352:254-266.

48. Grisendi S, Bernardi R, Rossi M, Cheng K, Khandker L, Manova K, Pandolfi PP: Role of nucleophosmin in embryonic development and tumorigenesis. Nature 2005, 437:147-153. 
49. Suvanto $P$, Wartiovaara $K$, Lindahl M, Arumae U, Moshnyakov M, Horelli-Kuitunen N, Airaksinen MS, Palotie A, Sariola H, Saarma M: Cloning, mRNA distribution and chromosomal localisation of the gene for glial cell line-derived neurotrophic factor receptor beta, a homologue to GDNFR-alpha. Hum Mol Genet 1997, 6:1267-1273.

50. Arighi E, Borrello MG, Sariola H: RET tyrosine kinase signaling in development and cancer. Cytokine Growth Factor Rev 2005, 16:44I-467.

5I. Ormandy CJ, Musgrove EA, Hui R, Daly RJ, Sutherland RL: Cyclin DI, EMSI and I IqI3 amplification in breast cancer. Breast Cancer Res Treat 2003, 78:323-335.

52. Wheeler MT, Zarnegar S, McNally EM: Zeta-sarcoglycan, a novel component of the sarcoglycan complex, is reduced in muscular dystrophy. Hum Mol Genet 2002, I I:2 I 47-2 I 54.

53. Arbieva ZH, Banerjee K, Kim SY, Edassery SL, Maniatis VS, Horrigan SK, Westbrook CA: High-resolution physical map and transcript identification of a prostate cancer deletion interval on 8p22. Genome Res 2000, 10:244-257.

54. Pils D, Horak P, Gleiss A, Sax C, Fabjani G, Moebus VJ, Zielinski C Reinthaller A, Zeillinger R, Krainer M: Five genes from chromosomal band 8p22 are significantly down-regulated in ovarian carcinoma: N33 and EFA6R have a potential impact on overall survival. Cancer 2005, 104:2417-2429.

55. Fridlyand J, Snijders AM, Ylstra B, Li H, Olshen A, Segraves R, Dairkee S, Tokuyasu T, Ljung BM, Jain AN, McLennan J, Ziegler J, Chin K, Devries S, Feiler H, Gray JW, Waldman F, Pinkel D, Albertson DG: Breast tumor copy number aberration phenotypes and genomic instability. BMC Cancer 2006, 6:96.

56. Wood LD, Parsons DW, Jones S, Lin J, Sjoblom T, Leary RJ, Shen D, Boca SM, Barber T, Ptak J, Silliman N, Szabo S, Dezso Z, Ustyanksky V, Nikolskaya T, Nikolsky Y, Karchin R, Wilson PA, Kaminker JS, Zhang Z, Croshaw R, Willis J, Dawson D, Shipitsin M, Willson JK, Sukumar S, Polyak K, Park BH, Pethiyagoda CL, Pant PV, Ballinger DG, Sparks AB, Hartigan J, Smith DR, Suh E, Papadopoulos N, Buckhaults $P$, Markowitz SD, Parmigiani G, Kinzler KW, Velculescu VE, Vogelstein $B$ : The genomic landscapes of human breast and colorectal cancers. Science 2007, $318: 1108-11113$.

57. Mohl M, Winkler S, Wieland T, Lutz S: Gefl 0-the third member of a Rho-specific guanine nucleotide exchange factor subfamily with unusual protein architecture. Naunyn Schmiedebergs Arch Pharmacol 2006, 373:333-34I.

58. Forget MA, Desrosiers RR, Del M, Moumdjian R, Shedid D, Berthelet $F$, Beliveau R: The expression of rho proteins decreases with human brain tumor progression: potential tumor markers. Clin Exp Metastasis 2002, 19:9-I5.

59. Mazieres J, Antonia T, Daste G, Muro-Cacho C, Berchery D, Tillement V, Pradines A, Sebti S, Favre G: Loss of RhoB expression in human lung cancer progression. Clin Cancer Res 2004, 10:2742-2750.

60. Liu AX, Rane N, Liu JP, Prendergast GC: RhoB is dispensable for mouse development, but it modifies susceptibility to tumor formation as well as cell adhesion and growth factor signaling in transformed cells. Mol Cell Biol 200I, 21:6906-69I2.

61. Wu GS, Burns TF, McDonald ER 3rd, Jiang W, Meng R, Krantz ID, Kao G, Gan DD, Zhou JY, Muschel R, Hamilton SR, Spinner NB, Markowitz S, Wu G, el-Deiry WS: KILLER/DR5 is a DNA damage-inducible p53-regulated death receptor gene. Nat Genet 1997, I 7:|4|-| 43.

62. Birnbaum D, Adelaide J, Popovici C, Charafe-Jauffret E, Mozziconacci MJ, Chaffanet M: Chromosome arm 8p and cancer: a fragile hypothesis. Lancet Oncol 2003, 4:639-642.

63. Popescu NC: Fragile sites and cancer genes on the short arm of chromosome 8. Lancet Oncol 2004, 5:77. discussion 77

64. Margolin AA, Greshock J, Naylor TL, Mosse Y, Maris JM, Bignell G, Saeed Al, Quackenbush J, Weber BL: CGHAnalyzer: a standalone software package for cancer genome analysis using array-based DNA copy number data. Bioinformatics 2005, 21:3308-3311.

\section{Pre-publication history}

The pre-publication history for this paper can be accessed here: http://www.biomedcentral.com/1471-2407/8/288/pre pub
Publish with Bio Med Central and every scientist can read your work free of charge

"BioMed Central will be the most significant development for disseminating the results of biomedical research in our lifetime. "

Sir Paul Nurse, Cancer Research UK

Your research papers will be:

- available free of charge to the entire biomedical community

- peer reviewed and published immediately upon acceptance

- cited in PubMed and archived on PubMed Central

- yours - you keep the copyright

Submit your manuscript here:

http://www.biomedcentral.com/info/publishing_adv.asp
BioMedcentral 